\title{
GMR
}

\section{Virulence and genetic diversity among isolates of Mycosphaerella fijiensis in two regions of Brazil}

\author{
G.F. Silva ${ }^{1}$, V.S. Santos ${ }^{1}$, N.R. Sousa ${ }^{2}$, R.E. Hanada $^{3}$ and L. Gasparotto ${ }^{4}$ \\ ${ }^{1}$ Laboratório de Biologia Molecular, Embrapa Amazônia Ocidental/CPAA, \\ Manaus, AM, Brasil \\ ${ }^{2}$ Embrapa Cocais, São Luiz, MA, Brasil \\ ${ }^{3}$ Laboratório de Fitopatologia, Instituto Nacional de Pesquisa da Amazônia, \\ Manaus, AM, Brasil \\ ${ }^{4}$ Laboratório de Fitopatologia, Embrapa Amazônia Ocidental/CPAA, Manaus, \\ AM, Brasil
}

Corresponding author: G.F. Silva

E-mail: gilvan.silva@embrapa.br

Genet. Mol. Res. 15 (2): gmr.15027797

Received October 7, 2015

Accepted December 3, 2015

Published April 26, 2016

DOI http://dx.doi.org/10.4238/gmr.15027797

\begin{abstract}
Black sigatoka, caused by the fungus Mycosphaerella fijiensis (anamorphic stage: Paracercospora fijiensis), was first detected in Brazil in early 1998 in the Benjamin Constant and Tabatinga municipalities in the State of Amazonas, near to where the borders of Brazil, Colombia, and Peru converge. Understanding how cultivars react to the pathogen, and characterizing the genetic variability of isolates from two distant and distinct banana-producing regions, are important for determining the virulence of $M$. fijiensis. In the present study, the genetic diversity of $22 \mathrm{M}$. fijiensis isolates was assessed using simple sequence repeats (SSR) markers, and their virulence was determined following inoculation on three different banana tree cultivars. All 22 isolates caused symptoms of the disease in the Maçã and Prata Comum cultivars 45 days after inoculation, and at least two virulence groups were identified for the Maçã and Prata Comum cultivars. For the
\end{abstract}


D'Angola cultivars, two virulence groups were observed only after 60 days post-inoculation, and three of the isolates were not virulent. Using SSR markers, the isolates from two different regions of Brazil were placed into two genetic groups, both genetically distant from the Mf 138 isolate collected in Leticia, Colombia. There was no evidence of correlation between the virulence groups and the genetic diversity groups. These results demonstrate variability in virulence between isolates as measured by the severity of black sigatoka in the analyzed cultivars.

Key words: Black sigatoka; Musa spp; SSR; Genetic variability; Fungal pathogen

\section{INTRODUCTION}

Black sigatoka, caused by the fungus Mycosphaerella fijiensis Morelet [anamorphic stage: Paracercospora fijiensis (Morelet) Deighton], is the most important disease in the major banana-producing regions of the world (Marín et al., 2003; Pennisi, 2010). The symptoms of this disease include brown streaks on abaxial leaf surfaces, which progress to black spots. The lesions cause the leaf to die, thereby reducing the photosynthetic capacity of the plant and preventing growth, resulting in small fruit that ripen unevenly. In banana trees derived from cultivars susceptible to black sigatoka, such as Prata, Nanica, Prata Graúda, and Prata Apodi, all of the leaves die approximately 60 days after flowering, and production losses can reach $100 \%$ (Gasparotto et al., 2006). In addition, disease control has been limited to the application of fungicides, which can increase the cost of production by up to $40 \%$, in addition to causing problems for the environment and being toxic to farmers and consumers (Marín et al., 2003).

The pathogen was first reported on the American continent in Honduras in 1972 (Stover and Dickson, 1976). In South America, the geographic expansion of the pathogen began in Colombia in 1981, Ecuador in 1986, Peru in 1994, and Bolivia in 1996 (Ganry et al., 2012). In Brazil, the disease was first reported in early 1998 in the Tabatinga and Benjamin Constant municipalities in the State of Amazonas where the Brazilian, Colombian, and Peruvian borders converge (Pereira et al., 1998). Currently, the disease is established in the State of Maranhão and the North, South, Southeast and Central East regions, except in the northern part of Minas Gerais, in the States of Espírito Santo, Goiás, and the Federal District.

Spores can be spread over long distances by wind, by infected seedlings, on fruit, on packages or vehicles that travel through affected plantations, and on the clothes of workers who have direct contact with infected banana plants (Hanada et al., 2002). The circulation of infected seedlings between producers and nurserymen may have facilitated the spread of the pathogen in the major Brazilian growing regions. The north and southeast regions are responsible for $50 \%$ of the national banana production, with a predominance of group $\mathrm{AAB}$ and group AAA cultivars (Lichtemberg et al., 2013).

The heterothallic nature of the pathogen increases its rate of genetic recombination and plays an important role in amplifying its genetic diversity, thus increasing the probability that new pathotypes and strains will appear (Carlier et al., 2003). In Brazil, data on matingtype distribution suggest that sexual recombination occurs randomly in the $M$. fijiensis population (Queiroz et al., 2013). Another potential source of genetic variation is the presence of transposable elements, which constitute $11.7 \%$ of the M. fijiensis genome (Santana et al., 2012).

The genetic variability of $M$. fijiensis populations in other banana-producing countries 
has been analyzed using several molecular markers, including restriction fragment length polymorphisms (RFLPs) (Carlier et al., 1996; Hayden et al., 2003), amplified fragment length polymorphisms (AFLPs) (Nakyanzi, 2002), polymerase chain reaction-RFLPs (PCRRFLPs) (Rivas et al., 2004), and variable number of tandem repeats (VNTRs) (Garcia et al., 2010). High polymorphism rates have been the main argument for the use of simple sequence repeats (SSRs) as molecular markers in studies investigating genetic variability in several species (Karaoglu et al., 2005).

The development of resistant cultivars is an ideal strategy for controlling the disease, as it would decrease production costs and the environmental impact. However, this process requires an understanding of the genetic variability and virulence the pathogen has acquired upon adaptation to different climatic conditions, cultivars, and agricultural systems. Analyzing genetic diversity is essential for guiding control strategies based on breeding or fungicide management in agricultural ecosystems (McDonald and Linde, 2002).

Thus, understanding how cultivars react to the pathogen and the genetic variability of isolates from two geographically distant regions with distinct banana-producing systems is important for measuring the specificity of the fungus. Therefore, the aims of the present study were to evaluate the virulence of 22 monosporic isolates of $M$. fijiensis used to inoculate three banana cultivars and to analyze their genetic diversity using SSR markers.

\section{MATERIAL AND METHODS}

\section{Obtaining isolates}

Samples of leaves presenting typical disease lesions were collected in three states, from two banana-producing regions of Brazil, and one in the city of Leticia - Colombia, on the Brazil-Colombian border (Table 1). The method described by Gasparotto et al. (2006) was used to isolate the fungus.

Monosporic isolates were transferred to Petri dishes containing V8 medium $(20 \mathrm{~g} / \mathrm{L}$ agar, $200 \mathrm{~mL} / \mathrm{L} \mathrm{V8,} 3 \mathrm{~g} / \mathrm{L} \mathrm{CaCO}_{3}$ ), and were incubated at $25^{\circ} \mathrm{C}$ for 10 days in the dark.

\section{Mycelial mass growth}

Colonies were ground and then spread onto four Petri dishes containing $20 \mathrm{~mL} \mathrm{V8}$ medium, after which they were incubated for 15 days at $25^{\circ} \mathrm{C}$. Mycelial suspensions were obtained by adding $5 \mathrm{~mL}$ distilled water to each plate. This was then removed and transferred to a $50-\mathrm{mL}$ beaker using a Drigalsky loop. The suspension was mixed using a Vortex at $500 \mathrm{rpm}$ for $3 \mathrm{~min}$ and filtered using sterile gauze. The concentration of the fragments was quantified by four readings in a Neubauer chamber and adjusted to $10^{5}$ fragments $/ \mathrm{mL}$.

\section{Analysis of virulence}

Virulence was analyzed using hyphal fragments as described previously by Donzelli and Churchill (2007). In addition, the virulence of the isolates was estimated by the reaction of three banana cultivars from the AAB group: D'Angola, Maçã, and Prata Comum. The experimental design was completely randomized with four replicates and a factorial design that included 22 isolates $\mathrm{x} 3$ cultivars. 
Table 1. Relationship of Mycosphaerella fijiensis isolates from banana cultivars in two regions of Brazil.

\begin{tabular}{|c|c|c|c|c|}
\hline Isolate & Region & Municipality & Cultivar & GPS coordinates \\
\hline Mf 001 & North & Presidente Figueiredo-AM & Maçã & 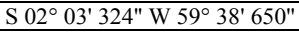 \\
\hline Mf 008 & North & Manacapuru-AM & D'Angola & - \\
\hline Mf 023 & North & Manacapuru-AM & Maçã & 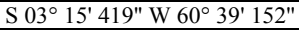 \\
\hline Mf 068 & North & Manacapuru-AM & D'Angola & 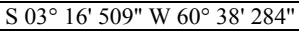 \\
\hline Mf 111 & North & Caroebe-RR & Pacovan & $\mathrm{S} 00^{\circ} 52^{\prime} 557^{\prime \prime} \mathrm{W} 59^{\circ} 41^{\prime} 725^{\prime \prime}$ \\
\hline Mf 120 & North & Caroebe-RR & Pacovan & S $00^{\circ} 48^{\prime} 268^{\prime \prime}$ W $59^{\circ} 25^{\prime} 838^{\prime \prime}$ \\
\hline Mf 121 & North & Caroebe-RR & Pacovan & S $00^{\circ} 47^{\prime} 823^{\prime \prime}$ W $59^{\circ} 25^{\prime} 722^{\prime \prime}$ \\
\hline Mf 138 & North & Letícia-Colômbia & D'Angola & S $04^{\circ} 08^{\prime} 236^{\prime \prime} \mathrm{W} 69^{\circ} 56^{\prime} 767^{\prime \prime}$ \\
\hline Mf 150 & North & Itacoatiara-AM & Prata Comum & 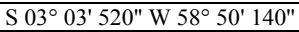 \\
\hline Mf 188 & North & Itacoatiara-AM & Maçã & 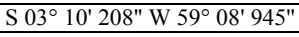 \\
\hline Mf 189 & North & Itacoatiara-AM & Caru-verde & 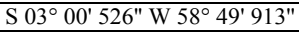 \\
\hline Mf 190 & North & Itacoatiara-AM & Prata Comum & 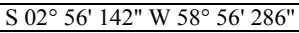 \\
\hline Mf 192 & North & Itacoatiara-AM & Nanica & 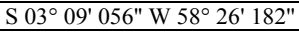 \\
\hline Mf 193 & North & Itacoatiara-AM & D'Angola & 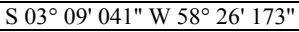 \\
\hline Mf 195 & North & Itacoatiara-AM & D'Angola & 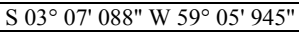 \\
\hline Mf 226 & North & Iranduba-AM & Prata Comum & 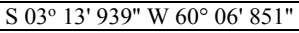 \\
\hline Mf 027 & Southeast & Cajati-SP & Prata Anã & $\mathrm{S} 24^{\circ} 48^{\prime} 475^{\prime \prime} \mathrm{W} 48^{\circ} 05^{\prime} 415^{\prime \prime}$ \\
\hline Mf 202 & Southeast & Pedro de Toledo-SP & Prata Anã & $\mathrm{S} 24^{\circ} 16^{\prime} 819^{\prime \prime} \mathrm{W} 47^{\circ} 13^{\prime} 139^{\prime \prime}$ \\
\hline Mf 206 & Southeast & Juquiá-SP & Prata Anã & $\mathrm{S} 24^{\circ} 18^{\prime} 770^{\prime \prime} \mathrm{W} 47^{\circ} 37^{\prime} 368^{\prime \prime}$ \\
\hline Mf 210 & Southeast & Eldorado-SP & Prata Anã & S $24^{\circ} 43^{\prime} 071^{\prime \prime} \mathrm{W} 48^{\circ} 11^{\prime} 207^{\prime \prime}$ \\
\hline Mf 216 & Southeast & Jacupiranga-SP & Nanicão & $\mathrm{S} 24^{\circ} 48^{\prime} 475^{\prime \prime} \mathrm{W} 48^{\circ} 05^{\prime} 415^{\prime \prime}$ \\
\hline Mf 218 & Southeast & Jacupiranga-SP & Prata Anã & $\mathrm{S} 24^{\circ} 42^{\prime} 185^{\prime \prime} \mathrm{W} 48^{\circ} 00^{\prime} 607^{\prime \prime}$ \\
\hline
\end{tabular}

Inoculations were performed on leaves 1 and 2 , in six $25-\mathrm{cm}^{2}$ sections, three on each side of the midrib at the apex, center, and base of the leaf. Analyses were performed at 45 and 60 days after inoculation using a modified version of the diagrammatic scale proposed by Gauhal (1994) as follows: 0, no symptoms; 1, lesions on less than 1\% leaf area; $2,1-5 \%$ leaf area contains lesions; 3, 6-15\% leaf area contains lesions; 4, 16-33\% leaf area contains lesions; 5, 34-50\% leaf area contains lesions; and 6, 51-100\% leaf area contains lesions. The data were transformed to $\sqrt{ }(x+0.5)$ and subjected to analysis of variance; then, the averages were compared using the Scott-Knott (1974) test at a 1\% level of significance.

\section{SSR analysis}

Isolates were cultured in liquid BD medium with agitation at $120 \mathrm{rpm}$ to obtain a mycelial mass that could be used for DNA extraction using the protocol described by Doyle and Doyle (1990). Samples were quantified using a spectrophotometer (NanoDrop, Thermo) and on $0.8 \%$ agarose gel to evaluate DNA quality. Fifteen SSR loci (Yang and Zhong, 2008; Zapater et al., 2008) were selected and used to analyze genetic diversity (Table 2). DNA amplification reactions were performed in a $15-\mu \mathrm{L}$ total volume with 0.3 $\mu \mathrm{M}$ each primer, $50 \mathrm{ng}$ DNA, $2 \mathrm{mM} \mathrm{MgCl}, 0.5 \mathrm{mM}$ dNTP, and $1 \mathrm{U}$ Taq-DNA polymerase (Phoneutria). The amplification conditions were as follows: 1 cycle at $94^{\circ} \mathrm{C}$ for $3 \mathrm{~min}, 40$ cycles at $94^{\circ} \mathrm{C}$ for $30 \mathrm{~s}$, specific annealing temperature of each primer for $1 \mathrm{~min}$, and $72^{\circ} \mathrm{C}$ for $2 \mathrm{~min}$, with a final extension at $72^{\circ} \mathrm{C}$ for $7 \mathrm{~min}$. Amplification products were visualized on a $6 \%$ polyacrylamide gel. The data were analyzed by recording the presence (1) or absence $(0)$ of a band for each isolate. Genetic similarity was estimated using the Dice coefficient, and a dendrogram was generated using the UPGMA method in NTSYSpc version 2.1. 
Table 2. Number of SSR alleles per locus used to characterize Mycosphaerella fijiensis isolates from Brazil.

\begin{tabular}{|c|c|c|c|}
\hline Locus & No. of alleles ${ }^{\mathrm{a}}$ & Repeat motif & Primer reference \\
\hline MfSSR-35 & 2 & $(\mathrm{AG})_{35}$ & Yang and Zhong (2008) \\
\hline MfSSR-41 & 2 & $(\mathrm{ACT})_{55}$ & Yang and Zhong (2008) \\
\hline MfSSR-50 & 2 & $(\mathrm{CAT})_{14}$ & Yang and Zhong (2008) \\
\hline MfSSR-54 & 2 & $(\mathrm{CCT})_{14}$ & Yang and Zhong (2008) \\
\hline MfSSR-62 & 2 & $(\mathrm{ATG})_{15}$ & Yang and Zhong (2008) \\
\hline MfSSR-65 & 2 & $(\mathrm{AG})_{16}$ & Yang and Zhong (2008) \\
\hline MfSSR-306 & 3 & $(\mathrm{GT})_{15}$ & Zapater et al. (2008) \\
\hline MfSSR-322 & 1 & $(\mathrm{AC})_{7}$ & Zapater et al. (2008) \\
\hline MfSSR-324 & 3 & $(\mathrm{TG})_{14}$ & Zapater et al. (2008) \\
\hline MfSSR-328 & 5 & $(\mathrm{GT})_{2} \mathrm{G}(\mathrm{GT})_{5}$ & Zapater et al. (2008) \\
\hline MfSSR-340 & 2 & $(\mathrm{CT})_{3}(\ldots)(\mathrm{CA})_{9}$ & Zapater et al. (2008) \\
\hline MfSSR-347 & 1 & $(\mathrm{AC})_{3}(\ldots)(\mathrm{CA})_{7}$ & Zapater et al. (2008) \\
\hline MfSSR-356 & 3 & $(\mathrm{CA})_{1} \mathrm{C}(\mathrm{CA})_{8} \mathrm{AAA}(\mathrm{CA})_{5}$ & Zapater et al. (2008) \\
\hline MfSSR-358 & 4 & $(\mathrm{AC})_{23}$ & Zapater et al. (2008) \\
\hline MfSSR-362 & 2 & $(\mathrm{GA})_{4}(\ldots)(\mathrm{GT})_{6}$ & Zapater et al. (2008) \\
\hline
\end{tabular}

\section{RESULTS}

\section{Virulence variation}

The $M$. fijiensis isolates showed variable virulence when inoculated on the three banana cultivars. All 22 isolates caused symptoms of the disease in the Maçã and Prata Comum cultivars at 45 days after inoculation (data not shown). The means test for the reaction between the three cultivars inoculated with $M$. fijiensis identified two distinct virulence groups at 60 days at a $1 \%$ level of significance (Table 3). Three isolates did not cause a reaction in the D'Angola cultivar (Mf 150, Mf 195, and Mf 216), whereas the Mf 210 isolate had the highest score of any isolate when inoculated on the Prata Comum cultivar. The isolates were classified into at least two virulence groups for the Maçã and Prata Comum cultivars, except for Mf 150, Mf 195, and Mf 216, which were not virulent in the D'Angola cultivar. These results show that there is variability in the virulence of the 22 isolates analyzed.

Table 3. Average severity of black sigatoka at 60-day post-inoculation in the cultivars Maçã, D’Angola, and Prata Comum.

\begin{tabular}{|c|c|c|c|}
\hline Isolate & & Cultivar & \\
\hline & Maçã & D'Angola & Prata Comum \\
\hline Mf 001 & $3.00^{\mathrm{AA}}$ & $1.50^{\mathrm{cB}}$ & $2.50^{\mathrm{aA}}$ \\
\hline Mf 008 & $3.00^{\mathrm{aA}}$ & $2.50^{\mathrm{bA}}$ & $3.50^{\mathrm{aA}}$ \\
\hline Mf 023 & $3.50 \mathrm{a}^{\mathrm{A}}$ & $2.00^{\mathrm{bB}}$ & $2.00^{\mathrm{aB}}$ \\
\hline Mf 027 & $2.75^{\mathrm{aA}}$ & $1.00^{\mathrm{cB}}$ & $3.25^{\mathrm{aA}}$ \\
\hline Mf 068 & $3.00^{\mathrm{aA}}$ & $2.00^{\mathrm{bA}}$ & $2.50^{\mathrm{aA}}$ \\
\hline Mf 111 & $3.00^{\mathrm{aA}}$ & $1.50^{\mathrm{cB}}$ & $2.50^{\mathrm{aA}}$ \\
\hline Mf 120 & $2.25^{\mathrm{bA}}$ & $3.00^{\mathrm{aA}}$ & $2.00^{\mathrm{aA}}$ \\
\hline Mf 121 & $1.50^{\mathrm{bA}}$ & $1.50^{\mathrm{cA}}$ & $1.00^{\mathrm{bA}}$ \\
\hline Mf 138 & $3.75^{\mathrm{aA}}$ & $2.00^{\mathrm{bB}}$ & $3.00^{\mathrm{aA}}$ \\
\hline Mf 150 & $3.50^{\mathrm{aA}}$ & $0.50^{\mathrm{dC}}$ & $2.25^{\mathrm{bB}}$ \\
\hline Mf 188 & $3.00^{\mathrm{aA}}$ & $1.00^{\mathrm{cB}}$ & $1.50^{\mathrm{bB}}$ \\
\hline Mf 189 & $2.75^{\mathrm{aA}}$ & $2.50^{\mathrm{bA}}$ & $2.00^{\mathrm{bA}}$ \\
\hline Mf 190 & $2.75^{\mathrm{aA}}$ & $1.25^{\mathrm{cB}}$ & $3.00^{\mathrm{aA}}$ \\
\hline Mf 192 & $3.25^{\mathrm{aA}}$ & $1.00^{\mathrm{cB}}$ & $1.50^{\mathrm{bB}}$ \\
\hline Mf 193 & $2.25^{\mathrm{bA}}$ & $3.25^{\mathrm{aA}}$ & $2.75^{\mathrm{aA}}$ \\
\hline Mf 195 & $2.00^{\mathrm{bA}}$ & $0.50^{\mathrm{dB}}$ & $2.00^{\mathrm{bA}}$ \\
\hline Mf 202 & $2.00^{\mathrm{bB}}$ & $1.50^{\mathrm{cB}}$ & $3.00^{\mathrm{aA}}$ \\
\hline Mf 206 & $1.75^{\mathrm{bB}}$ & $1.50^{\mathrm{cB}}$ & $3.00^{\mathrm{aA}}$ \\
\hline Mf 210 & $2.00^{\mathrm{bB}}$ & $2.50^{\mathrm{bB}}$ & $4.00^{\mathrm{aA}}$ \\
\hline Mf 216 & $2.75^{\mathrm{aA}}$ & $0.00^{\mathrm{dB}}$ & $3.00^{\mathrm{aA}}$ \\
\hline Mf 218 & $2.00^{\mathrm{bA}}$ & $1.50^{\mathrm{cB}}$ & $2.00^{\mathrm{bA}}$ \\
\hline Mf 226 & $2.00^{\mathrm{bB}}$ & $3.50^{\mathrm{aA}}$ & $3.00^{\mathrm{aA}}$ \\
\hline
\end{tabular}

Averages in the same column followed by the same letter are not different by the Scott-Knott test at 1\% probability. 
The severity of the disease in the cultivars varied for most of the isolates from the North region and for all of the isolates from the Southeast (Tables 2 and 3). Isolates from the North region were obtained from six different cultivars, and of these, six isolates did not show significantly different disease severity in D'Angola (Mf 008 and Mf 193), Pacovan (Mf 120 and Mf 121), and Caru-verde (Mf 189). When inoculated into their respective host, isolates from the Maçã cultivar (Mf 023 and Mf 188) showed more severe disease. The isolate from the Prata Anã cultivar (Mf 210) showed similar behavior, as it was more severe when inoculated on the Prata comum cultivar. The D'Angola cultivar was the least susceptible of the three cultivars that were artificially inoculated with isolates from the two regions of Brazil.

\section{SSR variation}

Analysis of the dendrogram generated from the SSR marker data divided the isolates from the two Brazilian regions into two groups, which were genetically distant from the isolate obtained from Leticia, Colombia. The first group consists of isolates from the three states representative of the Brazilian regions. This group contains two subgroups: one with the isolates Mf 111 (Roraima), Mf 195, and Mf 296 (Amazonas) and the other consisting of isolates from Amazonas and São Paulo (Figure 1).

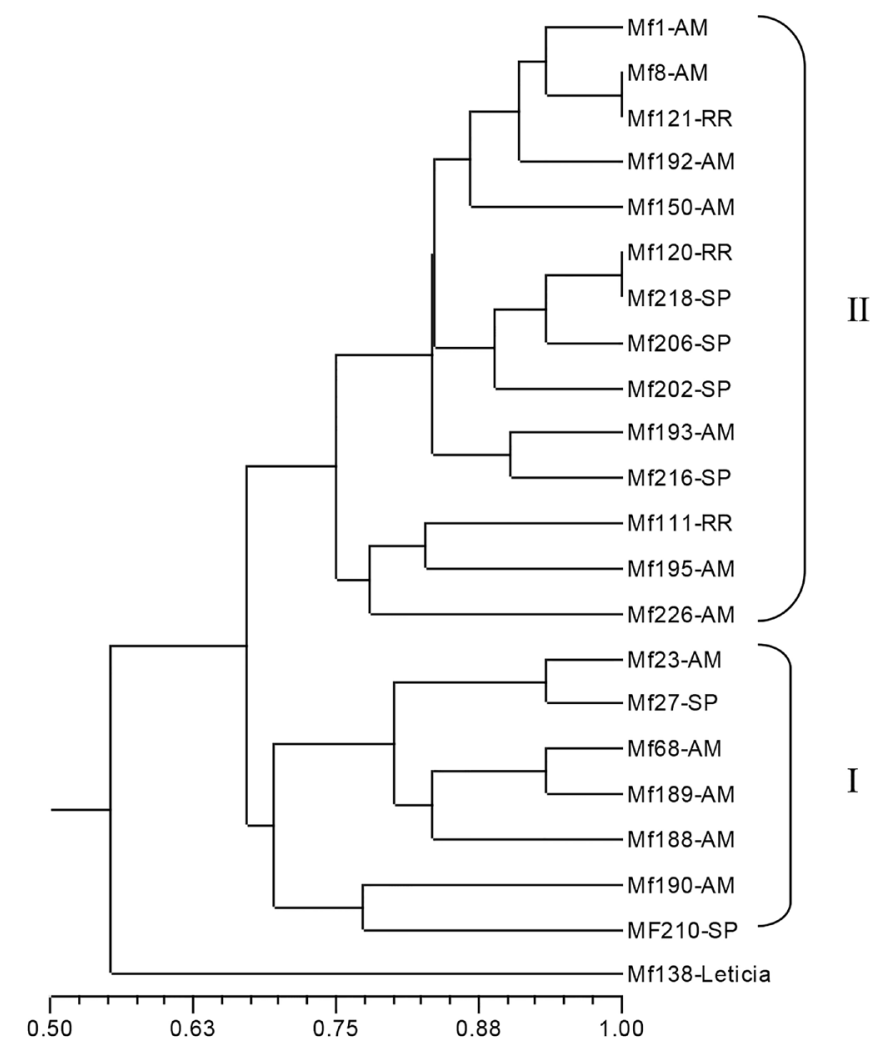

Figure 1. Dendrogram of 22 isolates of Mycosphaerella fijiensis created using the Dice coefficient similarity as estimated from microsatellite data. 
There was no evidence of a correlation between the virulence and genetic diversity groups, but the latter did contain a separate subgroup for isolates from the Prata Anã cultivar in the State of São Paulo. However, the creation of two similar groups suggests the initiation of genetic differentiation in M. fijiensis, influenced by heterogeneity in the host cultivars and agricultural ecosystems.

\section{DISCUSSION}

The two regions from which isolates were collected have distinct environmental conditions and production systems. In the Southeast region, the crops cover large areas and are predominately composed of a few cultivars. In contrast, several cultivars are planted in small areas in the North region. Adaptation to both mono- and multi-cultivar systems, together with the presence of sexual reproduction, may affect the extent of the pathogen's variability and may promote the rise of novel strains. Sexual reproduction can lead to a high degree of genetic variability and a limited amount of clonality, as has occurred globally in populations of the wheat pathogens Mycosphaerella graminicola and Phaeosphaeria nodorum (Chen and McDonald, 1996; Stukenbrock et al., 2006). The occurrence of parasexual cycles may also generate variation in an asexual population (Schoustra et al., 2007).

The results of the inoculation tests indicated variability in the virulence of isolates; however, this variability was limited by the levels of resistance exhibited by the banana cultivars exposed to the fungus. Banana tree genotypes considered to be highly resistant are characterized by a complete lack of symptoms and sporulation; while partially resistant genotypes present moderate disease, normal symptom development, and longer latency; and susceptible genotypes present rapidly developing disease symptoms and short latency (Fouré et al., 2000).

The genetic variability between populations may provide information on the recent history and movement of the pathogens (Gross et al., 2012). Microsatellite analysis provided some insight into the spread of $M$. fijiensis in the country, despite the limited sample size. The genetic similarity between isolates from different regions confirms that the pathogen migrates from north to south in Brazil. Spreading of plant pathogens across large distances is a common phenomenon that can occur naturally by the aerial dispersion of spores or by the movement of material and seeds from infected plants by humans (Stukenbrock et al., 2006).

The formation of three clusters of isolates from two distant regions suggests that these isolates are beginning to genetically differentiate despite their recent introduction to Brazil. In an analysis of two $M$. fijiensis populations with a recent colonization history (Costa Rica and Cameroon), Halkett et al. (2010) detected low-to-moderate genetic differentiation, but they suggested continual expansion of this phytopathogen as a result of gradual dispersion of spores over several hundred kilometers. The most recent analysis of the worldwide population structure of $M$. fijiensis showed that the global expansion of this wind-dispersed pathogen occurred via its unique successful introduction into the African continent and several introductions into the American continent (Robert et al., 2012), although samples from the Brazilian M. fijiensis population were not included in that study.

\section{Conflicts of interest}

The authors declare no conflict of interest. 


\section{ACKNOWLEDGMENTS}

Research supported by Embrapa (Brazilian Agricultural Research Corporation), the National Counsel of Technological and Scientific Development (CNPq-Conselho Nacional de Desenvolvimento Científico e Tecnológico), and the Amazon Research Foundation (FAPEAM-Fundação de Amparo à Pesquisa do Estado do Amazonas).

\section{REFERENCES}

Carlier J, Lebrun MH, Zapater MF, Dubois C, et al. (1996). Genetic structure of the global population of banana black leaf streak fungus, Mycosphaerella fijiensis. Mol. Ecol. 5: 499-510. http://dx.doi.org/10.1111/j.1365-294X.1996. $\underline{\text { tb00342.x }}$

Carlier J, Hayden H, Rivas G, Zapater MF, et al. (2003). Genetic differentiation in Mycosphaerella leaf spot pathogens. In: Mycosphaerella Leaf Spot Diseases of Bananas: Present Status and Outlook. Proceedings of the Workshop on Mycosphaerella Leaf Spot Diseases, San José, Costa Rica, 20-23 May 2002 (Jacome L, Lepoivre P, Marin D, Ortiz R, et al., eds.), Montpellier: The International Network for the Improvement of Banana and Plantain 123-129.

Chen RS and McDonald BA (1996). Sexual reproduction plays a major role in the genetic structure of populations of the fungus Mycosphaerella graminicola. Genetics 142: 1119-1127.

Donzelli BGG and Churchill ACL (2007). A quantitative assay using mycelial fragments to assess virulence of Mycosphaerella fijiensis. Phytopathology 97: 916-929. http://dx.doi.org/10.1094/PHYTO-97-8-0916

Doyle JJ and Doyle JL (1990). A rapid total DNA preparation procedure for fresh plant tissue. Focus 12: 13-15.

Fouré E, Mourichon X and Jones DR (2000). Black leaf streak. Hosp reation. Evaluating germplasm for reaction to black leaf streat. In: Disease of Banana, Abacá and Enset (Jones DR, ed.). CABI Publishing, Wallingford, 62-67.

Ganry J, Fouré E, Bellaire LL and Lescot T (2012). An integrated approach to control the black leaf streak disease (BLSD) of bananas, while reducing fungicide use and environmental impact fungicides for plant and animal diseases. In: Fungicides for Plant and Animal Diseases (Dhanasekaran D, ed.). InTech Europe, Rijeka, 214-216.

Garcia SAL, Van der Lee TAJ, Ferreira CF, Te Lintel Hekkert B, et al. (2010). Variable number of tandem repeat markers in the genome sequence of Mycosphaerella fijiensis, the causal agent of black leaf streak disease of banana (Musa spp). Genet. Mol. Res. 9: 2207-2212. http://dx.doi.org/10.4238/vol9-4gmr934

Gasparotto L, Pereira JCR, Hanada RE and Montarroyos AVV (2006). Sigatoka-Negra da Bananeira. Embrapa Amazônia Ocidental, Manaus, 177.

Gauhal F (1994). Epidemiology and ecology of black sigatoka (Mycosphaerella fijiensis Morelet) on plantation and banana (Musa spp.) in Costa Rica. Inibap, Montpellier, 120.

Gross A, Grünig CR, Queloz V and Holdenrieder O (2012). A molecular tool kit for population genetic investigations of the ash dieback pathogen Hymenoscyphus pseudoalbidus. For. Pathol. 42: 252-264. http://dx.doi.org/10.1111/ j.1439-0329.2011.00751.x

Halkett F, Coste D, Platero GG, Zapater MF, et al. (2010). Genetic discontinuities and disequilibria in recently established populations of the plant pathogenic fungus Mycosphaerella fijiensis. Mol. Ecol. 19: 3909-3923. http://dx.doi. org/10.1111/j.1365-294X.2010.04774.X

Hanada RE, Gasparotto L and Pereira JCR (2002). Sobrevivência de conídios de Mycosphaerella fijiensis em diferentes materiais. Fitopatol. Bras. 27: 408-411. http://dx.doi.org/10.1590/S0100-41582002000400013

Hayden HL, Carlier J and Aitken EAB (2003). Genetic structure of Mycosphaerella fijiensis populations from Australia, Papua New Guinea and the Pacific Islands. Plant Pathol. 52: 703-712. http://dx.doi.org/10.1111/j.13653059.2003.00883.x

Karaoglu H, Lee CMY and Meyer W (2005). Survey of simple sequence repeats in completed fungal genomes. Mol. Biol. Evol. 22: 639-649. http://dx.doi.org/10.1093/molbev/msi057

Lichtemberg LA, Gasparotto L, Cordeiro ZJM, Rodrigues MGV, et al. (2013). Sistemas de producción de musáceas en Brasil. In: Reunião Internacional Acorbat. Acorbat Internacional, 34-42.

Marín DH, Romero RA, Guzman M and Sutton TB (2003). Black sigatoka: An increasing threat to banana cultivation. Plant Dis. 87: 208-222. http://dx.doi.org/10.1094/PDIS.2003.87.3.208

McDonald BA and Linde C (2002). The population genetics of plant pathogens and breeding strategies for durable resistance. Euphytica 124: 163-180. http://dx.doi.org/10.1023/A:1015678432355

Nakyanzi M (2002). Molecular and pathogenic diversity of isolates of Mycosphaerella fijiensis that Sigatoka disease of banana in East África. Thesis (Doctor) - Natural Resources Institute- University of Greenwich, England, 232. 
Pennisi E (2010). Armed and dangerous. Science 327: 804-805. http://dx.doi.org/10.1126/science.327.5967.804

Pereira JCR, Gasparotto L, Coelho AFS and Urben AF (1998). Ocorrência da Sigatoka-negra no Brasil. Fitopatol. Bras. 23: 295.

Queiroz CB, Miranda EC, Hanada RE, Sousa NR, et al. (2013). Distribution of mating-type alleles and M13 PCR markers in the black leaf spot fungus Mycosphaerella fijiensis of bananas in Brazil. Genet. Mol. Res. 12: 443-452. http:// dx.doi.org/10.4238/2013.February.8.9

Rivas GG, Zapater MF, Abadie C and Carlier J (2004). Founder effects and stochastic dispersal at the continental scale of the fungal pathogen of bananas Mycosphaerella fijiensis. Mol. Ecol. 13: 471-482. http://dx.doi.org/10.1046/j.1365294X.2003.02043.X

Robert S, Ravigne V, Zapater MF, Abadie C, et al. (2012). Contrasting introduction scenarios among continents in the worldwide invasion of the banana fungal pathogen Mycosphaerella fijiensis. Mol. Ecol. 21: 1098-1114. http://dx.doi. org/10.1111/j.1365-294X.2011.05432.x

Santana MF, Silva JC, Batista AD, Ribeiro LE, et al. (2012). Abundance, distribution and potential impact of transposable elements in the genome of Mycosphaerella fijiensis. BMC Genomics 13: 720. http://dx.doi.org/10.1186/1471-2164$\underline{13-720}$

Schoustra SE, Debets AJM, Slakhorst M and Hoekstra RF (2007). Mitotic recombination accelerates adaptation in the fungus Aspergillus nidulans. PLoS Genet. 3: e68. http://dx.doi.org/10.1371/journal.pgen.0030068

Scott AJ and Knott MA (1974). A cluster analysis method for grouping means in the analysis of variance. Biometrics 30 : 507-512. http://dx.doi.org/10.2307/2529204

Stover RH and Dickson JD (1976). Banana leaf spot caused by Mycosphaerella musicola and M. fijiensis var. difformis: a comparison of the first Central American epidemics. FAO Plant Prot. Bull. 24: 36-42.

Stukenbrock EH, Banke S and McDonald BA (2006). Global migration patterns in the fungal wheat pathogen Phaeosphaeria nodorum. Mol. Ecol. 15: 2895-2904. http://dx.doi.org/10.1111/j.1365-294X.2006.02986.x

Yang BJ and Zhong SB (2008). Fourteen polymorphic microsatellite markers for the fungal banana pathogen Mycosphaerella fijiensis. Mol. Ecol. Resour. 8: 910-912. http://dx.doi.org/10.1111/j.1755-0998.2008.02113.x

Zapater MF, Duchemin M, Dussart JF, Coste D, et al. (2008). Microsatellite markers for the fungal banana pathogens Mycosphaerella fijiensis, Mycosphaerella musicola and Mycosphaerella eumusae. Mol. Ecol. Resour. 8: 1121-1125. http://dx.doi.org/10.1111/j.1755-0998.2008.02180.x 